Agnieszka Słoboda $\bullet$

Uniwersytet im. Adama Mickiewicza, Poznań

asloboda@amu.edu.pl

\title{
HISTORIA SKŁADNI JĘZYKA POLSKIEGO KRYSTYNY PISARKOWEJ - ŚWIADECTWO ZMIANY I ŹRÓDŁO INSPIRACJI
}

\begin{abstract}
Słowa klucze: Krystyna Pisarkowa, składnia historyczna, tendencje, procesy
Keywords: Krystyna Pisarkowa, historical syntax, tendencies, processes
\end{abstract}

Historia składni języka polskiego ukazała się w 1984 r., a więc nieomal 30 lat od wydania Gramatyki historycznej języka polskiego Zenona Klemensiewicza, Tadeusza Lehra-Spławińskiego i Stanisława Urbańczyka (Klemensiewicz, Lehr-Spławiński, Urbańczyk 1955). Przez ten czas część dotycząca składni ogólnego języka polskiego opracowana przez Z. Klemensiewicza, a także gromadzony i wydawany sukcesywnie najpierw pod jego kierunkiem, a następnie pod kierownictwem Krystyny Pisarkowej zbiór Zapomnianych konstrukcji składni (ZKSS, ZKSŚXVI, ZKSŚXVII, ZKSŚ1700-1780, ZKSN1780-1822, ZKSN1822-1863, ZKSN1863-1918) stały się nie tylko podstawą nauczania, ale i punktem odniesienia dla prowadzonych badań. Czas ten przyniósł również zmiany metodologiczne, rozwój analiz i modeli strukturalnych, w tym semantycznych i generatywnych, które w znaczący sposób wpływały na powstające opracowania cząstkowe, a także na perspektywę oglądu składni przez samą Pisarkową ${ }^{1}$. Mimo że model opisu Klemensiewiczowskiego stanowił dla Niej punkt wyjścia, ponieważ był, jak pisała, „uporządkowaniem najpewniejszym

1 Widać to chociażby w uwzględnionej w bibliografii i wykorzystanej w książce ogromnej liczbie monografii i artykułów poświęconych składni historycznej, wśród których znalazło się aż 27 prac samej autorki. 
i najbezpieczniejszym" (Pisarkowa 1984: 8), z jednej strony znacznie jego granice rozszerzyła, z drugiej - w porównaniu z opracowaniem Klemensiewicza - zawęziła. Owo zawężenie dotyczy zakresu materiału - o ile Klemensiewicz opisywał zarówno struktury ciągłe, jak i nieciągłe w historii składni, o tyle autorce zależało przede wszystkim na przeanalizowaniu struktur nieciągłych, będących świadectwem zmiany językowej i tym samym uzasadniających potrzebę opisu diachronicznego.

Celem takiego opisu nie jest jednak ustalenie dokładnej charakterystyki zmienności systemu składniowego, niemożliwe jest bowiem na podstawie dostępnego materiału formułowanie wniosków ogólnych: „Mówiąc o ostrożności w uogólnianiu, myślę o tym, że nie można układać na podstawie materiału polskiego bardzo dokładnego obrazu zmiany ani też dać opisu zmienności systemu składniowego w ogóle” (ibid.: 6). Argumentując, autorka przywołuje Raimo Anttilę: „dla każdego $\mathrm{z}$ indoeuropejskich języków trzeba by napisać gramatyki na identycznych zasadach, aby wydobyć różnice obiektywne (nie wynikające z różnic opisów)" (ibid.: 5). Poziom najwyższy takiego opisu ogólnego byłby już poziomem gramatyki uniwersalnej.

Jaki jest zatem sens uprawiania polskiej składni historycznej? Dla Pisarkowej to stworzenie takiego opisu, który historię składni ukazywałby jako historię umiejętności składniowego kształtowania tekstu. Sens teoretyczny stanowiłby więc efekt dodatkowy i przyczynkowy wobec sensu praktycznego:

Sens niewątpliwy, a zarazem praktyczny i szczegółowy, to nie tylko ukazanie [...] opisu zmian w systemie syntaktycznym [...]. Jest to po pierwsze możliwość dostarczenia materiału i nawet rozwiązań, rozstrzygnięć dla teorii i praktyki kultury języka. [...] Po drugie jest to [...] możliwość empirycznego, nie wymodelowanego odkrycia struktur pierwotnych lub choćby pierwotniejszych, surowych lub „surowszych”, wyjściowych w stosunku do odbijających wtórne, późniejsze stadia ewolucji, np. kondensacji (struktury „absolutne”, „zanurzone” itd.) (ibid.: 6).

Aby wskazany cel zrealizować, składnia historyczna powinna mieć charakter kontrastywny, a punktem odniesienia musi być współczesna polszczyzna, zarówno w odmianie pisanej, jak i mówionej. Punktem wyjścia należy uczynić zjawiska wewnątrzjęzykowe, ponieważ, jak pisze Pisarkowa: „Badanie tych zjawisk jest zawsze możliwe i zawsze konieczne, podczas gdy badanie zjawisk zewnętrznych jest nie zawsze możliwe i nie zawsze konieczne" (ibid.: 8$)^{2}$. Takie badanie nie może jednak odbywać się za pomocą metody przekrojów synchronicznych: „Nie można opisywać systemów poszczególnych periodów we wzajemnych opozycjach, ani tym bardziej wychodzić od zjawisk ogólniejszych i kategorialnych, obserwując ich zmienność na tle stałości innych” (ibid.: 6). Przyczyną owej niemożności jest relatywizm katego-

2 Takie podejście, nazwane „ewolucją perspektywiczną”, reprezentuje w badaniach słowotwórczych, w zakresie wyrażeń funkcyjnych ściśle powiązanych ze składnią, Krystyna Kleszczowa (2003, 2015). 
rii składniowych, który wpływa na sposób przeprowadzania analizy, w tym przede wszystkim na określanie granic zdania i jego składników. Dotyczy to nieostrych różnic między zdaniem i równoważnikiem zdania, zdaniem prostym i złożonym (co wiąże się między innymi z brakiem interpunkcji w najdawniejszych tekstach), zdaniami podrzędnymi i współrzędnymi (ze względu na homonimię wskaźników nawiązania), a także płynnej granicy między modalizatorami i okolicznikami oraz między dopełnieniami i okolicznikami (ibid.: 9-10). Problemem jest również, według Pisarkowej, brak idealnego strukturalistycznego opisu dla systemu synchronicznego (w zakresie składni) ${ }^{3}$.

Ze względu na tego typu czynniki autorka postuluje odejście od statycznego modelu opisu, choć, jak zauważa, „sama synchronia jest podobnie jak pojęcie systemu językowego przydatną abstrakcją naukową" (ibid.: 10). Diachroniczne ujęcie opisu składniowego wymaga natomiast sformułowania „systemu” tendencji: „Pewne jest bowiem, że wszystkie systemy naturalne zawierają w sobie tendencje dynamiczne" (ibid.). Owo poszukiwanie tendencji, które odbywa się na każdym poziomie opisu składniowego, uwzględnia przy tym obecność nieukierunkowanych zmian ewolucyjnych (jak na przykład ruchomość i wahania w obrębie argumentów implikowanych i nieimplikowanych). Stają się one wraz z innymi procesami niezbędnym kontekstem dla wspomnianego sytemu tendencji, ponieważ ,inaczej wygląda podobna zmiana oglądana w izolacji niż na tle kontekstu innych zmian" (ibid.: 8).

Przystępując do opisu zmian składniowych, Pisarkowa pozostaje częściowo przy tradycyjnym modelu zdania i jego głównych kategoriach, takich jak zdanie proste i złożone, podmiot i orzeczenie, określniki grupy podmiotu i określniki grupy orzeczenia itp. Świadectwem zmiany jest przesunięcie punktu ciężkości na semantykę, analiza konstrukcji nacechowanych modalnie, rozwinięcie analizy wypowiedzeń zestawionych (odniesienie do pragmatyki i teorii aktów mowy), opis wypowiedzeń złożonych podporządkowany wskazanym tendencjom. Autorka sięga przy tym do terminologii składni logiczno-semantycznej, zwraca uwagę na różnice między strukturą powierzchniową i semantyczną wypowiedzenia, stopień zanurzenia dodatkowej predykacji w strukturę zdania pojedynczego, kwestie implikacji oraz kwantyfikacji, co w znacznym stopniu nie tylko poszerza perspektywę samego opisu, ale też umożliwia uchwycenie natury zachodzących zmian. W podsumowaniu kolejnych rozdziałów przedstawia wyodrębnione przez siebie tendencje, a także wskazuje granice czasowe wymienionych procesów. Należy tu podkreślić, że odnotowane tendencje często pokrywają się z procesami, co wynika z faktu podporządkowania opisu poszczególnym poziomom struktury

3 To, czy dysponujemy już takim modelem i czy można go wykorzystać w badaniach diachronicznych, wciąż jest pytaniem otwartym, na co wskazują dyskusje toczone zarówno wśród historyków języka, jak i badaczy współczesnej polszczyzny (zob. Pastuch, Siuciak 2016; Mika, Rojszczak-Robińska, Ziółkowska 2018). 
składniowej ${ }^{4}$. Wśród najważniejszych zatem procesów i tendencji wskazanych przez Pisarkową należałoby wymienić następujące:

1) W związku głównym: tendencję do wykształcania dwuczłonowego schematu zdania: S + P; modyfikację podmiotu przy zaistnieniu dodatkowych informacji semantycznych (przypadek podmiotu w grupach kwantyfikowanych ilościowo, podmiocie złożonym, nacechowaniu modalnym); wyrównanie przypadka podmiotu do mianownika, co prowadzi do konfliktu między funkcją semantyczną kategorii morfologicznej a strukturą składniową (zgoda); kształtowanie czasowników posiłkowych; ogólną tendencję do eliminowania struktur skondensowanych, zintegrowanych przez struktury proste, bliskie takiemu wzorcowi, w których suma elementów formalnych odzwierciedla płaskie, lecz jednoznaczne odbicie zawartości semantycznej; przechodzenie struktur biernych w bezpodmiotowe i bezosobowe; formalne różnicowanie zdań jednoczłonowych i zdań z podmiotem domyślnym (ibid.: 62-65).

2) W grupie czasownikowej w ramach związków z okolicznikiem: przejście od form kazualnych do przysłówków; kostnienie form wycofujących się (kazualnych) w wyrażenia frazeologiczne (ibid.: 91-92).

3) W grupie czasownikowej w ramach związków z obiektem (argumentem konotowanym przez predykat): zmianę rekcji ze względu na semantykę; czworakie zmiany w relacji przypadek-wyrażenie przyimkowe: a) kazus > kazus, b) kazus > $>$ prepozycja + kazus, c) prepozycja + kazus $>$ prepozycja + kazus, d) prepozycja + kazus > kazus; tendencję do przekształcenia składni syntetycznej w analityczną; ; tendencję do specjalizacji semantycznej (określone połączenia przyimka z przypadkiem), przy czym możliwą fazą końcową procesów jest przechodzenie $\mathrm{w}$ tendencję do wahań, ambiwalencji lub nawet wymarcia jednej $\mathrm{z}$ alternatywnych form składniowych; zyskiwanie lub utratę tranzytywności (ibid.: 116-121).

4) W grupie imiennej: możliwe zmiany i przesunięcia przebiegają w kierunkach zaprogramowanych przez warianty składni w grupie - kongruencja może się przekształcić w rekcję, rekcja w kongruencję lub w inną rekcję; predykaty zanurzone mogą się rozwijać w wypowiedzenie złożone parataktycznie lub hipotaktycznie; występowanie nazw własnych (a więc elementów o referencji jednostkowej) w grupie rozbudowanej o element denotacyjny (rama 'meta'); zmiany w grupach z nazwą własną kwantyfikowaną ilościowo (nazwy jednostek miar) i w konstrukcjach posesywnych (ibid.: 141-142).

5) W ramach złożonych konstrukcji zdaniowych ogromną rolę według Pisarkowej odgrywa upiśmiennienie: „Rozwijanie wypowiedzenia złożonego jest jednocześ-

4 Proces rozumiem jako przebieg w czasie następujących po sobie, pozostających we wzajemnej zależności zmian jakiegoś stanu, natomiast tendencję jako kierunek zmiany. Proces jest zatem przejawem tendencji (zob. Krążyńska, Mika, Słoboda 2015: 18) 
nie połączone z ogromnym wysiłkiem oddzielenia języka pisanego od mowy" (ibid.: 176), które reprezentują różne stopnie i warianty integralności składniowej. Wśród procesów i tendencji powiązanych z tą fundamentalną zmianą wskazać należy: tendencję do przechodzenia od konstrukcji nierozrywalnych, nacechowanych morfologicznie (na przykład narzędnik predykatywny, tryb syntaktyczny, bezokolicznik) z dużym ładunkiem semantycznym, przez konstrukcje z partykułami, spójnikami i przysłówkami, do zdań ze skorelowanymi wskaźnikami zespolenia (ibid.).

6) W ramach wypowiedzeń nacechowanych modalnie (modalność rozumiana jest jako stosunek nadawcy do wypowiedzi) tendencją ogólną jest wzrastająca złożoność struktury składniowej, ponadto: konstrukcje składniowe i elementy leksykalne zastępują lub wspomagają ułomne tryby nacechowane: rozkazujący i przypuszczający; wykładniki leksykalne i syntaktyczne nacechowane modalnie mogą ulegać gramatykalizacji i leksykalizacji (ibid.: 205).

7) W obrębie konstrukcji zestawionych obserwujemy z jednej strony tendencję, żeby spójność zestawienia sygnalizowana była wykładnikami dystansu między oboma tekstami zestawionymi (wprowadzenie cytatu), z drugiej - tendencję, aby gwarantować spójność związków składniowych (mowa zależna); równoczesne działanie obu tendencji prowadzi do kontaminacji mowy zależnej i niezależnej oraz wypowiedzenia zestawionego ze złożonym (ibid.: 221-222).

8) W obrębie wypowiedzeń złożonych (dwukrotnie) należy przede wszystkim wskazać tendencję do kształtowania opozycji parataksy i hipotaksy; przechodzenie od zespoleń bezspójnikowych do wskaźników zespolenia; starzenie się i wymieranie wskaźników zespolenia; odnawianie wskaźników zespolenia - zmianę funkcji i znaczenia przez uzupełnianie spójnika partykułą lub innym spójnikiem; kształtowanie się skorelowanych wskaźników zespolenia (ibid.: 245).

Wszystkie wskazane tendencje i procesy zilustrowane są w tekście drobiazgowymi analizami szczegółowych zagadnień, które otwierają pole do dyskusji, dalszych analiz, są inspiracją do uzupełniania przestrzeni opisu składniowego w aspektach nieuwzględnionych w pełni przez Pisarkową, jak na przykład zmiany w obrębie wyrażeń funkcyjnych czy funkcje składniowe nominalizacji.

Autorka zwróciła uwagę na ogromny wpływ semantyki na zmienność systemu składniowego:

[...] funkcja semantyczna morfemu i leksemu różni się od funkcji semantycznej fonemu. Jej aktualizacja dokonuje się w większym kontekście. Oznacza to, że dokonuje się ona w kontekście syntaktycznym, co ma ogromne znaczenie także dla składni. [...] zmienna semantyka morfemów i leksemów przyczynia się bardziej niż jakiekolwiek (bezpośrednie czy pośrednie) czynniki interakcji społecznej do przekształcania funkcji elementów w struktury syntaktyczne, a w następnym kroku także samej struktury syntaktycznej (ibid.: 7-8). 
Równie inspirującym zagadnieniem jest „różnorodność zanurzenia w leksyku lub zależności struktury składniowej od leksyku i stopnie podatności na zmiany właśnie w zależności od stopnia zanurzenia w leksyku" (ibid.: 9) ${ }^{6}$.

Pisarkowa stawia także przed swoimi następcami zadania o charakterze bardziej fundamentalnym, a ich realizacja możliwa jest jedynie w wyniku uogólniania wniosków pochodzących z badań szczegółowych nie tylko zjawisk nieciągłych, ale również tych obecnych w polszczyźnie od najdawniejszych czasów. O ile te ostatnie potwierdzają tezę o konserwatyzmie składni i są istotnym punktem odniesienia, o tyle pierwsze nadają w ogóle sens analizie historycznej (ibid.: 12). Do owych zagadnień fundamentalnych zalicza Pisarkowa: nieodwracalność zmiany językowej (w składni); nacechowanie reliktów nieproduktywnych (w składni, ale może to dotyczyć również słownika lub frazeologii); nacechowanie pozytywne jako przedmiot reguły i negatywne jako wyjątek w regule; relację między zmianą analogiczną a uproszczeniem oraz uproszczeniem a „elaboracją"; kwestię leksykalizacji; odporność form częstych na zmiany; reinterpretację jako czynnik zmiany; równowagę systemu, granice tej równowagi, możliwość jej utraty (ibid.: 6). Lista ta wciąż pozostaje inspiracją dla każdego badacza składni historycznej.

\section{Literatura}

Klemensiewicz Z., Lehr-Sp£awiński T., UrbańCzyk S., 1955, Gramatyka historyczna języka polskiego, Warszawa.

KleszCzOwA K., 2003, Staropolskie derywaty przymiotnikowe i ich perspektywiczna ewolucja, „Prace Naukowe Uniwersytetu Śląskiego w Katowicach”, nr 2176, Katowice.

KLESzCzowA K., 2015, U źródeł polskich partykuł. Derywacja funkcjonalna, przemiany, zani$k i$, „Prace Naukowe Uniwersytetu Śląskiego w Katowicach”, nr 3368, Katowice.

KrążyŃska Z., Mika T., SŁoboda A., 2015, Składnia średniowiecznej polszczyzny, cz. I: Konteksty, metody, tendencje, Poznań.

Mika T., Rojszczak-Robińska D., ZıóŁkowska O. (red.), 2018, Terminy w językoznawstwie synchronicznym i diachronicznym, „Staropolskie Spotkania Językoznawcze”, t. 3, Poznań.

Mika T., SŁoвоdA A., 2015, Wyrażenia funkcyjne w średniowiecznej polszczyźnie z perspektywy składniowej. Wybrane problemy badawcze, Poznań.

Pastuch M., SiUciak M. (red.), 2018, Historia języka w XXI wieku. Stan i perspektywy, „Prace Naukowe Uniwersytetu Śląskiego w Katowicach”, nr 3670, Katowice.

PIsarkowa K., 1984, Historia składni języka polskiego, „Prace Instytutu Języka Polskiego”, nr 52, Wrocław.

ZKSN1780-1822: Zapomniane konstrukcje składni nowopolskiej (1780-1822). Wybór przykładów, oprac. A. Kałkowska i in., Wrocław 1974.

6 Inspiracje te znalazły wyraz w pracach poświęconych wyrażeniom funkcyjnym (Kleszczowa 2015) czy składni najdawniejszej polszczyzny (Krążyńska, Mika, Słoboda 2015; Mika, Słoboda 2015). 
ZKSN1822-1863: Zapomniane konstrukcje składni nowopolskiej (1822-1863). Wybór przykładów, oprac. A. Kałkowska i in., Wrocław 1975.

ZKSN1863-1918: Zapomniane konstrukcje składni nowopolskiej (1863-1918). Wybór przykładów, oprac. A. Kałkowska i in., Wrocław 1977.

ZKSS: Zapomniane konstrukcje składni staropolskiej. Wybór przykładów, oprac. Z. Klemensiewicz, K. Pisarkowa, J. Konieczna-Twardzikowa, Wrocław 1966.

ZKSŚXVI: Zapomniane konstrukcje składni średniopolskiej (XVI wiek). Wybór przykładów, oprac. Z. Klemensiewicz i in., Wrocław 1971.

ZKSŚXVII: Zapomniane konstrukcje składni średniopolskiej (XVII wiek). Wybór przykładów, oprac. A. Kałkowska, K. Pisarkowa, J. Twardzikowa, Wrocław 1972.

ZKSŚ170o-1780: Zapomniane konstrukcje składni średniopolskiej (170o-1780). Wybór przykładów, oprac. A. Kałkowska i in., Wrocław 1973.

\section{Krystyna Pisarkowa's The History of Polish Syntax - The Testimony of Change and the Source of Inspiration \\ Abstract}

The author of the article shows Krystyna Pisarkowa's monograph as a text which presents a diachronic approach to Polish syntax in a new and modern way, taking into account the times and the Polish linguistic tradition. Focusing on discontinuous phenomena in the history of the Polish language, Pisarkowa separates tendencies and processes typical of each syntactic level. Not only does she discuss traditionally described elements of simple and complex utterances, but she also takes into account the semantic structure of sentences and their pragmatic aspect. Therefore, Historia składni języka polskiego [The History of Polish Syntax] is a testimony of a methodological change and a quest for adequate solutions, as well as a source of inspiration for further generations of researchers. 